\title{
Morphological Features in the English Language of Selected Nigerian Paramilitary Formations in Akwa Ibom State
}

\author{
God'sgift Ogban Uwen ${ }^{1}$ \\ ${ }^{1}$ Department of English and Literary Studies, University of Calabar, Nigeria. E-mail: godsgiftuwen@yahoo.com
}

Received: March 11, 2019

Accepted: March 27, 2019

Online Published: March 31, 2019

doi:10.5430/elr.v8n1p48

URL: https://doi.org/10.5430/elr.v8n1p48

\begin{abstract}
This paper seeks to investigate the official communicative activities among Nigerian paramilitary formations in Akwa Ibom State, with a view to determining the peculiar forms generated through morphological processes that occur in their interactions. The agencies selected for the study are: the Nigeria Police Force, the Federal Road Safety Corps and the Nigeria Security and Civil Defence Corps. The theoretical framework adopted for, and considered relevant to the study is Lieb's Theory of Process Model of Word Formation. The theory offers a comprehensive approach which accounts for all processes of word formation in a unified way. Data used for the study were collected through participant observation and unstructured interview of personnel while on duty within the office environment using random sampling method. The findings indicate that the operatives used English language for their formal conversations to communicate paramilitary ideology. In addition, they were found to have used unique lexical choices created specifically to serve the communication needs of the interlocutors. It is therefore recommended that operatives of these agencies should 'simplify' their morphologically-conditioned terminologies in particular, and the language in general, such that the public which they are meant to serve could understand.
\end{abstract}

Keywords: Paramilitary formations, English language, Communication needs, Words formation, Lexical choices.

\section{Introduction}

Language is the vehicle for communication in any human field of endeavour. It is multifaceted in nature and functions; its use, more often than not, is aimed at communicating ideology or belief. Irrespective of discourse participants, every communicative activity is influenced by an ideology which informs language choice and usage (Medubi, 2003; Goodwyn \& Stables, 2004). Language therefore functions as an indicator of ideological stances which manifest in social situations where speech activities occur. So, speech events, either in whole or part, reflect the beliefs of the interactants; that is, the language of a group reflects their social and physical environment (Akinmameji, 2016; Ijomah, 1973). The peculiarity of where ideologically-motivated discourse activities range from individuals, groups to societies. The beliefs tend to 'reframe' the lexical choices that social groups 'create' for use, especially in interactions that involve members.

The level of grammar for consideration in this study is morphology. Ndimele (2003) and (Udofot, 2010) define morphology as the branch of linguistics which studies the internal structure of words and the rules governing how words are formed. The rules also explain the various processes which new words are formed. The focus is on English, which is the official language in Nigeria, which is used also by operatives of the paramilitary in their official engagements. It implies that, in the 'English language' of the paramilitary formations, there are peculiar constructions that exclude members from other social groups. Such peculiarity could be determined by the group's register. Register is a "particular set of lexical items associated with a form of language linked to one's area of human experience and endeavour" (Nwafor, p. 41). The peculiarity in terms of register, in Nwofor's opinion, reflects in all levels of grammar. Therefore, the processes of word formation should generate new words that are mutually intelligible among the Nigerian paramilitary formations generally.

\subsection{Research questions}

1. What are the morphological processes adopted by the Nigerian paramilitary formations to create peculiar words for their use in Akwa Ibom State?

2. Are these creations mutually intelligible to, and among their counterparts in other States in Nigeria? 
3. Does the use of the constructions seclude 'civilians' from the formal speech activities of the operatives?

4. To what extent does the use of such forms facilitate the performance of their safety and security-related duties?

\section{Literature Review}

Although there have been a few researches on the language of the military and/or the paramilitary, there is a dearth of investigations (solely) on unique words they generate for use through morphological operation - word formation processes in English language. For instance, (Megbulem, 1991), (Alabi, 2014) and (Ogundele, 2016) have conducted researches on the context of military parades (where the paramilitary derives from) in Nigeria. Megbulem takes the linguistic perspectives, Alabi views parades as unique speech situations that portray linguistic 'deviation and choices' while Ogundele sees the parade scene as the contextual interplay of the three semantic constructs: field, tenor and mode of discourse. Each of them discovers unique lexical choices influenced by the situational contexts in the parade drills of the military.

In another direction, (Amafah, 1990) has done a study on the English language of the Nigerian Army; (Ebong, 2009) investigates style in the language of the Nigeria Police Force while (Uwen, 2017; Uwen \& Ekpe, 2018b) have examined language use in paramilitary formations, particularly; the Nigeria Police Force (NPF), the Nigerian Immigration Service (NIS), the Federal Road Safety Corps (FRSC), the National Drug Law Enforcement Agency (NDLEA) and the Nigeria Security and Civil Defence Corps (NSCDC). Amafah and Ebong make a skeletal description of the subject. However, Uwen (2017) enumerates a few morphological features in the language of the paramilitary while (Uwen \& Ekpe, 2018b) aver that the morphological forms in (and) the group's language enhance national development. The dominant findings among the scholars include the description of the prescriptive nature of the military (and by extension paramilitary) language without details on the application of the word formation processes to generate (new) words for use by the group in their conversational encounters. Therefore, this paper discusses word formation processes as conventional method for generating linguistic items as they apply in the language of paramilitary operatives (NPF, FRSC and NSCDC) in Akwa Ibom State in particular, with a view to examining the uncommon forms arising from such 'creations' that exist in their vocabulary.

\section{Methodology}

The methods adopted for this study were participant observation, oral (unstructured) interviews and secondary materials from the internet and library. Spontaneous communicative activities of the subjects were observed as well as a segment of the operatives (informally) interviewed using random sampling technique. Notes taken in the process were developed as data for this study, in addition to materials retrieved from the internet and library.

\section{Theoretical Framework}

There are perhaps no theories comprehensive enough to account for the various processes of words formation in English that takes into consideration the dynamic nature of the language. Rather than theories, there appears to be more emphasis on concepts and/or aspects of morphology. These include such concepts like word-formation (Quirk \& Greenbaum, 2000; Kosur, 2014), word-formation processes (Ndimele, 2003; Kemmer, 2016; Nordquist, 2017), generative morphology (Spencer, 2006), and inflectional and lexical morphology (Collins \& Hollo, 2010), among others. The scholars separately explain how new words are formed through morphologically-conditioned word formation rules.

However, Stekauer (1998) and Lieb (2013), among other scholars, have postulated theoretical concepts on words formation. Stekauer's Onomasiological theory appears deficient (in this context) because it emphasizes on 'naming needs of a speech community' and dispenses with the traditional word formation processes. Lieb's theory of process model of word formation is considered for this study. The theory emphasizes on basic processes of word formation, construes all processes involved in word formation in a unified way, draws a distinction between what is morphological and syntactic in word formation and specifies the interlink with some words and their paradigms. The theory, no doubt, accounts for insightful information required for investigations pertaining to word formation process in English.

\section{Words Formation Processes in the Paramilitary}

The English language of the personnel of the NPF, FRSC and NSCDC in Akwa Ibom State, like other social groups, operates in a simultaneous combination of the four subfields of linguistics: morphology, phonology, syntax and semantics. The level of language considered in this study is morphology; specifically the traditional words formation processes adopted by members of this group to form new words used in communicative events among members. The 
communicative needs of the Nigerian paramilitary formations particularly necessitate the use several but peculiar lexical choices, some of which are formed through the conventional morphological processes: blending, clipping, borrowing, compounding, debasing and acronyms/abbreviations. In other studies, bail bond, check point, death trap, traffic offences, oil thief, among others, were listed as collocations in paramilitary expressions while sitrep, intrep, notal, pasep, and so on as blended words. Also, clipped words such as info, loc, ops and ack, and acronyms/abbreviations: SARS, FIR, CERP, CIPU, SWAT, CID and many others have described as morphological properties in paramilitary language (Uwen, 2017; Uwen \& Ekpe, 2018b). However, apart from the fact the studies were not elaborate, they also limited the discussion on how such secluded expressions are used by the personnel to foster national development. Each of these processes as it applies to this study is discussed below.

\subsection{Blending}

Blending is the combination of parts of two or more existing words to form new words without any regard for where one morpheme ends and another begins; a kind of amalgamations of parts of different words (Ndimele, 2003; Kemmer, 2016; Nordquist, 2017). In blended words, letters, rather than syllables of words, are combined (joined) together to form new words. Blends found to be used by the operatives of these agencies include the following:

$\begin{array}{ll}\text { Sitrep: } & \text { Situation report } \\ \text { Intrep: } & \text { Intelligence report } \\ \text { Wilco: } & \text { Will comply } \\ \text { Pasep: } & \text { Pass Separately } \\ \text { Ingenpol: } & \text { Inspector General of Police } \\ \text { Comgen: } & \text { Commandant General } \\ \text { Corsec: } & \text { Corps Secretary } \\ \text { Forsec: } & \text { Force Secretary } \\ \text { Compol: } & \text { Commissioner of Police } \\ \text { Commace: } & \text { Corps Marshal }\end{array}$

In the blended words above, Sitrep, intrep, Comgen, Corsec, Forsec and Compol are realized by joining the first three letters of the two words. Also, wilco takes the first three letters of the first word and two from the second, pasep takes two from the first word and three from the second, whereas Ingenpol combines two letters of the first word, three from the second, ignores the third and takes three from the fourth. Similarly, in realizing the blend; Commace, the initial two alphabets of the two words are combined in addition to the 'importation' of the medial ' $\mathrm{m}$ ' and the end 'ce'. These indicate that the formation of blended forms does not take a regular pattern in terms of the number of alphabets considered from the two or more components words to form the new word.

\subsection{Clipping}

Clipping is a process of words formation where the existing word is reduced or shortened without changing its meaning; derived by deleting parts of the base word (Kosur, 2014; Nordquist, 2017). The deletion of the initial or end (part) of the word does not alter in any sense alters the meaning of the original word. The clipped forms found to be in the lexicon of this group include:

Loc: Location

Int: Intelligence

Ack: Acknowledged

Serg: $\quad$ Sergeant

Cons: Constable

Morn: Morning

In the clipped forms above, the first three words: loc, int and ack, are reduced from their lengthier versions to the three initial alphabet, while there are four alphabet in the other three words; serg, cons and morn. This also ascertains that clipping does not take into consideration the length of the original word in the realization of the 'shortened' form. The number of letters in the 'reduced' form is also found to be irregular as seen above; while some have three, the others have four. 


\subsection{Borrowing}

Borrowing involves the bringing of lexical items for use from one language and the retention in the vocabulary of the other. According to Uwen (2017), language use in the paramilitary formation is dependent on the bulk of lexical forms that altogether constitute the language associated with the paramilitary as a profession. The operatives also make use of words 'borrowed' from indigenous Nigerian and foreign languages which in most times are used in the informal context. The borrowed words and their meanings include:

\section{Yoruba}

Oga: boss, leader or superior.

Egunje: bribe, kickbacks, inducement or gratification.

Igbo

Ewu: a goat or someone who behaves in a similar (confused) manner, usually used to refer to recruits.

\section{Hausa}

Kai: exclamation expressed most often to correct or alert someone.

Yarinya: often used to refer to a female paramilitary operative.

\section{Nigerian pidgin}

Otondo: $\quad$ a fat and lazy person. A term used to refer to recruits who are reluctant to adapt to paramilitary regimentation.

French

Espirit de corps: moral of a group, spirit of oneness, usually expressed by the operatives to show solidarity.

\section{Spanish}

Guerrilla: a member of a small group fighting against irregular forces.

\section{Russia}

AK-47(Kalashnikov): An assault rifle named after the Russian manufacturer, usually called kalash for short.

The borrowed forms above reflect the dynamic nature of English as a language that borrows from other languages to increase its vocabulary. Aside from the borrowed items from foreign languages; espirit de corps, guerrilla and kelash, the lexical forms from Nigerian Pidgin: otondo, Igbo; ewu, Hausa; kai and yarinya, and Yoruba; oga and egunje, portray the operatives as bilinguals drawn from the Nigerian diverse sociolinguistic environment.

\subsection{Compounding/Collocational Restrictions}

Compounding as a word formation process involves the 'joining together' of two bases to form one word. According to Katamba (2016) compounding refers to the 'appropriate' combination of nouns, adjectives, verbs, adverbs or prepositions to form complex words. Katamba's assertion centres more on combination of word classes to form complex words. Kemmer (2016) also define compounding as the formation of a word from two or more root morphemes. It occurs with a hyphen (-), space or without space between the elements, or two bases joined together without a separation. Like other English compound words, the meaning of the new word often differs from the meaning of the individual words put separately. Also, there is a limit to which words can collocate; this limit defines some restrictions on how words of the same or different parts of speech can be used together. Uwen (2017) sees such combinations as collocating compounds. These include the following:

$\begin{array}{lll}\text { Noun } & + \text { Noun } & \text { Compounds } \\ \text { Team } & + \text { leader } & \text { team leader } \\ \text { Traffic } & + \text { offence } & \text { traffic offence } \\ \text { Accident } & + \text { victim } & \text { accident victim } \\ \text { Oil } & + \text { thief } & \text { oil thief } \\ \text { Parade } & + \text { commander } & \text { parade commander } \\ \text { Head } & + \text { gear } & \text { headgear } \\ \text { Exhibit } & + \text { yard } & \text { exhibit yard }\end{array}$




\begin{tabular}{|c|c|c|}
\hline Adjective & $+\quad$ Noun & Compounds \\
\hline Criminal & gang & criminal gang \\
\hline Reprobate & offender & reprobate offender \\
\hline Private & security & private security \\
\hline Principal & suspect & principal suspect \\
\hline Inflammable & liquid & inflammable liquid \\
\hline Verb & Noun & Compounds \\
\hline Gun & shot & gun shot \\
\hline Summary & trial & summary trail \\
\hline Traffic & alert & traffic alert \\
\hline
\end{tabular}

These compounds, though not exhaustive, are contained in the enlarged registers of the paramilitary formations. These are realized through the combination of nouns, adjectives and nouns, verbs and nouns, and nouns and adjectives. Aside from the two nouns that form the compound 'headgear' in which the two words which form the compound are fused together, the other forms have space between the two words. Although no hyphen (-) is used in any of the examples above, the meanings of the compounds are different from the individual words viewed separately.

\subsection{Acronyms/abbreviations}

Acronyms are more often represented in upper case. There are formed from combining the initial letters of other words. Abbreviations rather take the initial alphabet and/or the with medial or end alphabet. The examples peculiar to the language of the paramilitary agencies under study are:

OC: $\quad$ Officer in Charge

SOJ: $\quad$ Staff Officer (junior)

CRU: Complaint Response Unit

CID: Criminal Investigation Department

SOS: $\quad$ Staff Officer (Senior)

FIR: $\quad$ First Information Report

SO: $\quad$ Station Officer

DO: $\quad$ Duty Officer

OPS: Operations

SHOOPS: Sector Head of Operations

POWA: Police Officers Wives Association

CLA: $\quad$ Corps Legal Officer

SPEO: $\quad$ Sector Public Enlightenment Officer

ROSOWA: Road Safety Officers Wives Association

CTU: $\quad$ Counter Terrorists Unit

CIPU: Critical Infrastructure Protection Unit

SWAT: $\quad$ Special Weapons and Technical Team

ACO: $\quad$ Area Command's Office

CDOWA: Civil Defence Officers Wives Association

The above acronyms take the initial letters of the entire words represented in capital letters. However, ROSOWA, SWAT, OC and OPS show that most acronyms and abbreviations also contain some irregular patterns. In the acronym ROSOWA for instance, the first two letters are derived from the word 'Road', the end alphabet ' $\mathrm{T}$ ' for 
'Team' is omitted in SWAT and no letter represents the 'in' between ' $\mathrm{O}$ ' and ' $\mathrm{C}$ ' in $\mathrm{OC}$ while the abbreviation OPS takes the two initial alphabets 'op' and the end letter ' $\mathrm{s}$ '.

\subsection{Debasing}

Debasing is a label coined by Uwen (2017) to account for forms retained in the register of Nigerian paramilitary formations that are formed through the 'corruption' of their original English lexical items. Such words created through this process, a lot of which are phonologically conditioned are believed to be occasioned by mother tongue interference, but have been crystallized over the years for use by these agencies. The unique characteristic of these 'debased' forms is that they convey the meaning(s) of their original English lexical terms. The examples are:

\section{Word}

Ajuwaya:

Shun, tion:

Sharap:

Atis:

Prei:

Hep high:

Standa ais:

\section{English equivalent}

as you were

attention

shut up

at ease

parade (as in commands)

left right

stand at ease

As indicated above, 'ajuwaya' is a corrupt version of the phrase 'as you were' which means calling a parade to a relaxed position, 'shun' or 'tion' is the shortening of the longer word 'attention', 'sharap' is the corruption of the two words 'shut up' while 'atis' is realized from the pronunciation of 'at ease' as a single word instead of two as they appear. Similarly, 'prei', 'hep high' and 'standa ais' have the English equivalents as 'parade', 'left right' and 'stand at ease' respectively. They are all 'deviations' from their original forms. Aside from the debased form 'sharap', other expressions are also imperatives used exclusively during parade drills which in the parade context denote commands. These commands generate corresponding professionally-prescribed body movements decoded and encoded by the operatives.

\section{Conclusion}

The study has demonstrated that the NPF, FRSC and NSCDC in Akwa Ibom State, Nigeria, adopt for use the traditional word formation processes to generate new and uncommon words. They create words through blends, compounds, clipped items, debased forms, borrowed terms and acronyms/abbreviations which portray the peculiarity of the paramilitary linguistic pattern. The forms are believed to be intelligible among group members in the research area and those in other States in Nigeria. These isolated forms often exclude outsiders from participating in speech events involving the operatives, especially in official contexts. The use of such unique terminologies have been proven to have facilitate the performance of their official tasks which are safety and security in nature.

The study also showed that institutional practices and job schedules have enormous influence on language. The operatives, like employees of other government's institutions in Nigeria, use English in their official communicative activities. English language in this circumstance can be 'moulded' in terms of lexical deviations and choices to reflect the peculiar communication needs of organisations such as the paramilitary.

Given the fact that these agencies operate within an outnumbering civilian population (environment), scholars are encouraged to increase researches on the language of the paramilitary and disseminate same to bridge the gap of the occasional comprehension challenges experience by non-members. The personnel should also 'decode' and 'simplify' such institutionally-induced lexical forms to the understanding of the civilian populace which they are engaged and committed to serve.

\section{References}

Alibi, T. A. (2014). Language of the military: An Appraisal of a speech situation of Man O'War. Accessed from www.unilorin.edu.ng/publications/alabitalfig...on July 4, 2014.

Amefah, J. F. (1990). The English Language of the Nigerian Army: Situational and linguistic analysis. An unpublished PhD Thesis, Department of English, University of Ibadan.

Carstairs-McCarthy, A. (2002). An introduction to English morphology: Words and their structure. Edinburgh: Edinburgh University Press. 
Collins, P., \& Hollo, C. (2010). English grammar: An Introduction. London: Palgrave Macmillan. https://doi.org/10.1007/978-0-230-36576-6

Ebong, S. E. (2009). A stylistic study of the language of the Nigerian Police. An unpublished MA Thesis, Department of English, University of Uyo.

Goodwyn, A., \& Staples, A. (2004). Language and literacy. London: Sage.

Ijomah, B. C. I. (1978). The Sociological significance of language. In Anozie S. O. (Ed). Language system in Africa. New York: Centch Magazine.

Katamba, F. (2016). English morphology. Accessed from hppts//:www.ll.ac.uk/resources/gpg/209.html on March 9, 2018.

Kemmer, S. (2016). Types of words formation processes. Accessed from www.ruf.rice.edu>kemmer>wordtypes on March 9, 2018.

Korsur, H. M. (2014). Word formation: Creating new words in English. Accessed from http://www.brighthubeducation.com on March 31, 2018.

Lieb, H. (2013). Towards a general theory of word formation: The process model. Berlin: Freie Universität Berlin.

Medubi, O. (2003). Language and ideology in Nigerian Cartoons. In Driver, R. \& Frank, R. (Eds). Cognitive sociolinguistics. Germany: University of Duis-Burg.

Megbulem, C. (1991). The language of military parade in Nigeria. Accessed from mzwriters.com/project-categories/ar...on September 13, 2016.

Ndimele, O. (2003). A first course on morphology and syntax. Port Harcourt: Enhai Press.

Nordquist, R. (2017). Word formation. Retrieved from https://www.thoughtco.com/word.formation-16250 on March 26, 2017.

Nwofor, E. A. (1990). Language varieties: Focus on Nigeria. Onitsha: Common Wealth Publishers.

Ogundele, T. (2016). The context of Nigerian military parade interaction. In Odebunmi, A. \& Ayoola, K. A. (Eds), Language, Context and society. Ile-Ife: OAU Press.

Quirk, R., \& Greenbaum, S. (2000). University grammar of English. Essex: Pearson Education Ltd.

Spencer, A. (2006). Morphological theory and English. Accessed from https://www.researchgate.net/publication/39100311.

Stekauer, P. (1998). An onomasiological theory of English word formation. Berlin: John Benjamins. https://doi.org/10.1075/sfsl.46

Udofot, I. M. (2010). An Introduction to the morphology of English. Lagos: The Quantum.

Uwen, G. O. (2017). Language use in selected Nigerian paramilitary formations in Akwa Ibom State. An unpublished PhD Thesis. Department of English and Literary Studies, University of Calabar.

Uwen, G. O. \& Ekpe, S. I. (2018b). Language and National Development: The case of Nigerian Security Organisations. Calabar Journal of Liberal Studies, 20(2), 328-336. 